\title{
Synthesis of Infectious Viroids and Other Circular RNAs
}

\author{
M. A. Rezaian \\ CSIRO Plant Industry Horticulture Unit, Adelaide Laboratory, \\ PO Box 350, Glen Osmond SA 5064, Australia
}

\begin{abstract}
Viroids are small autonomously replicating RNAs that share structural features with other subviral circular single-stranded RNAs of plants. Viroids and other circular single-stranded RNAs can be synthesised in vitro by a PCR-based procedure using a simple set of reactions. Two end-to-end primers are selected from a desired region of the viroid, one for the synthesis of the first strand cDNA and another for the production of the second strand DNA. The second primer contains an 18 nucleotide $\mathrm{T} 7$ promoter at its $5^{\prime}$ end, and is selected such that the $G$ nucleotide at the transcription start site represents a $G$ in the viroid. Linked reverse transcription-PCR results in linear double-stranded DNA consisting of the viroid sequence and the $\mathrm{T} 7$ promoter. Run-off transcription of the PCR product allows the synthesis of exact-length linear viroid RNA which can be circularised by T4 RNA ligase following an enzymic modification of the 5 ' triphosphate to a monophosphate. This procedure results in authentic viroid molecules and obviates the need for construction and cloning of DNA in the form of tandem repeats for infectivity tests. It also allows PCR-based manipulation of circular RNAs, thus greatly simplifying structure-function analyses of viroid molecules.
\end{abstract}

\section{Introduction}

Viroids, the smallest pathogenic nucleic acids known, are unencapsidated circular single-stranded RNAs of about 240-400 nucleotides with extensive internal base pairing resulting in rod-like secondary structures. So far they have only been found in plants and include the causal agents of several crop diseases. Viroids do not appear to encode proteins and must therefore depend on unidentified host functions for their replication (1). Unlike viroids, which replicate autonomously, there are several other subviral circular RNAs that depend on helper viruses for replication. These include plant circular RNA satellites (2) and the viroid-like hepatitis delta RNA (3).

Site-directed mutagenesis of infectious viroid cDNA clones (4) has been widely used to study sequences required for viroid replication and pathogenicity (5). The infectivity of DNA clones and their respective transcripts depends on the presence of longer than unit length viroid sequence in the DNA constructs $(6,7)$. Mutational analysis of viroids therefore requires multiple DNA manipulations and cloning steps, which limits the number of viroid mutants produced for biological assays. An alternative procedure that circumvents cloning steps has been developed by Rigden and Rezaian (8). It involves reverse transcription/PCR reactions followed by in vitro transcription. A subsequent report (9) also describes essentially the same RNA synthesis procedure. 
Step 1: Synthesis of double-stranded cDNA

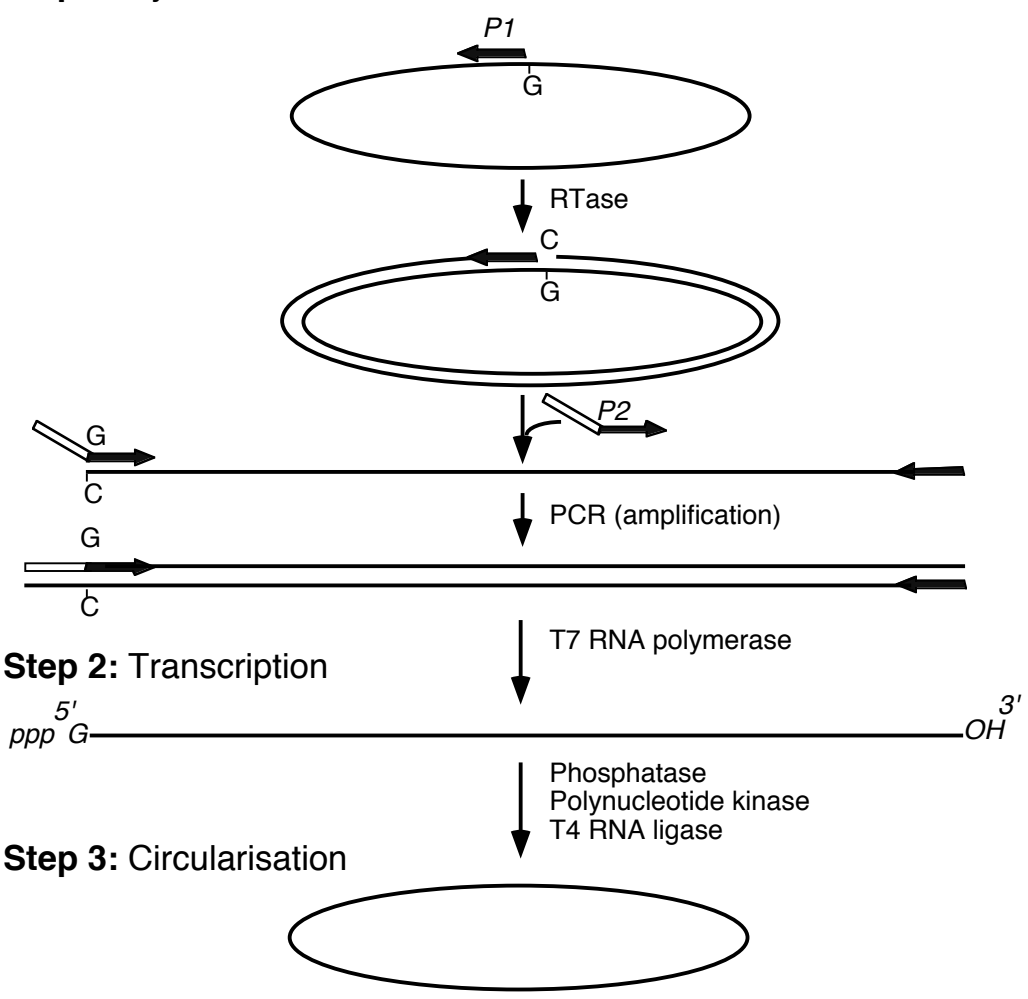

Figure 1. Scheme for in vitro synthesis of circular RNA. After Rigden and Rezaian (8) with permission from Academic Press.

\section{Scheme for the In Vitro Synthesis of Viroids}

A first-strand primer of 25-30 deoxyribonucleotides (P1, Figure 1) complementary to any region of the viroid $5^{\prime}$ to a $\mathrm{G}$ is annealed to the viroid RNA. Reverse transcription results in a full length cDNA containing a $\mathrm{C}$ complementary to the $\mathrm{G}$ nucleotide selected as transcription start site. The second strand primer (P2, Figure 1) consists of the 18 nucleotide $\mathrm{T} 7$ promoter up to the initiation site (dTAATACGACTCACTATAG) (10) linked to a viroid specific sequence of about 15 nucleotides complementary to the $3^{\prime}$ end of the cDNA. The guanosine nucleotide at position 18 in $\mathrm{P} 2$ is common to the two segments and is complementary to the $3^{\prime}-$ $\mathrm{C}$ in the unit length viroid cDNA. Second-strand synthesis is achieved and the DNA is amplified by PCR. The resulting double-stranded DNA contains a complete T7 RNA polymerase promoter and codes the exact-length viroid sequence. Transcription of the DNA by T7 RNA polymerase produces full-length linear viroid. The linear RNA can be circularised by RNA ligase after modifying its 5 '-triphosphate to monophosphate (Figure 1 step 3).

\section{The 1st Strand Primer}

Primers for the synthesis of 1st strand cDNA may be selected from any region of the circular RNA molecule. However, the high degree of secondary structure in viroid 
molecules may prevent annealing of some primers to the template RNA. It may be advantageous to use the predicted viroid secondary structure as a guide for selecting the 1st strand primer such that its 3'-end is located in a loop region.

At least partial sequence data is required for primer design. Sequence information is available for most viroids and pathogenic circular RNAs reported to date in nucleic acid database libraries (see ref. 11 for compilation). When sequence data is lacking, conventional techniques used for viroid sequencing, including partial enzymic digestion methods, may be used but these require relatively large quantities of viroid RNA and the direct RNA sequencing method is inaccurate. A PCR-based procedure using primers containing random hexamer at their $3^{\prime}$ end (12) has proven useful for obtaining clones of uncharacterised viroids (13) and can be used for sequencing viroid cDNA.

\section{The Template}

Viroid RNA is extracted from infected tissues of appropriate hosts by published procedures (eg. Ref. 14) and purified by a 2-dimensional electrophoresis procedure developed by Schumacher et al., (15). This technique is highly reproducible and can be used for both analytical and preparative purposes. In the 1st dimension, circular RNA together with comigrating host RNA species are separated from the bulk of host nucleic acids under non-denaturing conditions. In the second dimension, electrophoresis under denaturing conditions is carried out, which results in separation of circular RNA as a slowly migrating species relative to the contaminating linear plant RNAs. Virus-associated circular pathogenic RNAs are encapsidated and may be separated from virus preparations.

Two-dimensional gel purification may not always be necessary, as partially purified viroid preparations are frequently adequate for use as templates. Such preparations should be diluted suitably to minimise possible effects of interfering compounds in plant nucleic acid extracts. When DNA clones of circular RNAs are available, they may be used as templates. However, the possibility offered by circular RNA templates for synthesising circularly permuted full-length transcripts from desired points on the molecule can only be achieved with clones containing dimeric or longer viroid repeats. Monomer viroid inserts in circular plasmids can not substitute for circular viroid RNA templates due to the presence of vector sequences.

\section{Protocol}

\section{Synthesis of cDNA}

Double-stranded cDNA is synthesised by a combined reverse-transcription/PCR (16) as outlined in Table 1. Step 4 is only required in cases when the input template RNA is not desirable, such as in infectivity testing of the final viroid product.

\section{In Vitro Transcription}

Template DNA is transcribed with T7 RNA polymerase (17) as outlined in Table 1. Following the reaction, the transcription product should be examined for quality. This may be done by electrophoresis in a denaturing $6 \%$ polyacrylamide gel containing $8 \mathrm{M}$ urea using Tris-borate-EDTA buffer (18). RNA product is detected by staining with ethidium bromide or by silver (19). Prior to electrophoresis, samples of the transcription reaction may be digested separately with RNase and DNase to distinguish the transcription product from input DNA template. Alternatively, radioactive UTP can be incorporated into the RNA product, which aids the identification of transcript from input template.

The transcription step can be scaled up to produce even mg quantities of RNA. The Ribomax system (Promega) has been used for large-scale synthesis of peach latent mosaic viroid (9). 


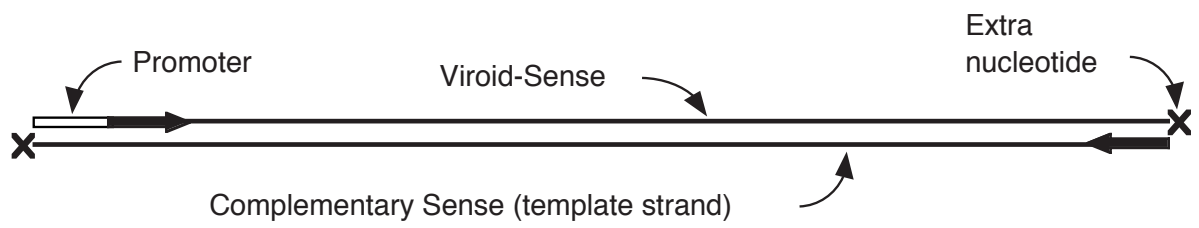

Figure 2. Schematic illustration of transcription DNA template produced by PCR.

\section{Modification of 5'-termini and Circularisation of RNA Transcripts}

The RNA molecules produced by in vitro transcription possess 3'-OH and 5'triphosphate termini. The 5'-triphosphate is removed by calf intestinal phosphatase and 5'-monophosphate termini are produced using polynucleotide kinase (18). If necessary, a parallel reaction with $\left[\gamma^{32} \mathrm{P}\right]$-ATP may be used to monitor phosphate incorporation. The reaction conditions for modifying the 5 '-termini and for the circularisation step with T4 RNA ligase(20) are outlined in Table 1.

\section{Verifying the Sequence at the Ligation Junction}

Taq DNA polymerase is known to incorporate a template-independent base at the 5 -end of the newly synthesised chain (21). However, this extra nucleotide should not affect the nature of viroid transcript because the 5 '-end of the template strand in the PCR product (Figure 2) where transcription terminates is derived from the input primer, rather than from synthesis during PCR. Nevertheless, the sequence at the ligation junction or reversion of modified bases engineered in viroids, which is likely to occur during replication in plants, may require verification. For this purpose a DNA fragment including the ligation junction can be amplified by RT/PCR and sequenced directly using T7 DNA polymerase (22).

\section{Biological Activity}

The viroid synthesis procedure was first developed (8) to synthesise biologically active citrus exocortis viroid (CEVd). Both linear and circular monomeric CEVd RNAs produced were indistinguishable from the corresponding species isolated from infected plants, when analysed by electrophoresis (Figure 3). Two independent unit-length linear RNA transcripts initiating from different points on the circular CEVd molecule were produced and examined for infectivity in host plants. Interestingly, the linear transcripts were found to be fully infectious, while the amplified DNA lacked infectivity. Upon circularisation, the infectivity of CEVd transcripts increased by about two orders of magnitude.

Linear viroids isolated from plants may be intermediates in rolling circle replication (1) but are also produced by random cleavage of the circular molecules (14). In contrast, RNA transcripts produced in vitro are homogeneous and discrete species of known end structure. The infectivity tests with linear CEVd enabled characterisation of the 5 '-end structure required for infectivity (8) and showed that a $2^{\prime}, 3^{\prime}$-cyclic phosphate at the terminus was not a prerequisite for infectivity as had been suggested.

Recently, the procedure was used to synthesise exactly-sized linear forms of potato spindle tuber viroid (23). The linear transcripts were shown to adopt the same conformation as the circular viroid. The in vitro-synthesised viroid was biologically active and was used for detailed structural analyses. Circular and linear forms of peach latent mosaic viroid have also been produced using the same in vitro synthesis principles but an infectivity test has not been reported (9). 
Table 1. Protocol for in vitro synthesis of circular RNA

\section{Synthesis of cDNA}

1. Add $2 \mu \mathrm{l}$ each of the two primers at $10 \mu \mathrm{M}$ concentration to the template circular RNA (about 10 ng) in a volume of $6 \mu 1$

2. Heat the mixture at $85^{\circ} \mathrm{C}$ for two min, then transfer to room temperature

3. Carry out combined reverse transcription and amplification in a volume of $100 \mu \mathrm{l}$ containing the template and primers, $10 \mathrm{mM}$ Tris- $\mathrm{HCl}$ ( $\mathrm{pH} 8.3$ at room temperature), $50 \mathrm{mM} \mathrm{KCl}, 2 \mathrm{mM} \mathrm{MgCl}$ $10 \mu \mathrm{g} / \mathrm{ml}$ gelatine, $200 \mu \mathrm{M}$ each of the four dNTPs, 4 units AMV reverse transcriptase, and 2 units of Taq DNA polymerase. Incubate the mixture at $42^{\circ} \mathrm{C}$ for $15 \mathrm{~min}$ followed by a 30 cycle PCR program of $1 \mathrm{~min}$ at $94^{\circ} \mathrm{C}, 1 \mathrm{~min}$ at $55^{\circ} \mathrm{C}$, and $2 \mathrm{~min}$ at $72^{\circ} \mathrm{C}$.

4. Incubate the amplified DNA with RNase A $\left(10 \mu \mathrm{g} / \mathrm{ml}, 37^{\circ} \mathrm{C}, 30 \mathrm{~min}\right)$ to digest the input template RNA if desired. Remove the RNase by phenol extraction.

5. Remove primers from the DNA by electrophoresis in agarose (17), by ultrafiltration, or by a silica gel basedPCR-DNA purification kit (eg. Qiagen Cat No. 28104).

\section{Transcription}

1. Transcribe $100 \mathrm{ng}$ template DNA in $20 \mu \mathrm{l}$ reaction containing $0.5 \mathrm{mM}$ of each rNTP, $40 \mathrm{mM}$ Tris$\mathrm{HCl}$, pH 7.6, $6 \mathrm{mM} \mathrm{MgCl} 2,0.1 \mu \mathrm{g} / \mu \mathrm{l}$ acetylated BSA (Promega), $10 \mathrm{mM}$ dithiothreitol, and 0.5 units/ $\mu 1 \mathrm{~T} 7 \mathrm{RNA}$ polymerase.

2. Incubate the mixture at $37^{\circ} \mathrm{C}$ for $30 \mathrm{~min}$.

3. Examine product quality by electrophoresis (see the text)

\section{Circularisation}

1. Incubate approximately $100 \mathrm{ng}$ of RNA with 1 unit of RNase-free calf intestinal phosphatase in 10 $\mathrm{mM}$ Tris- $\mathrm{Hcl}, \mathrm{pH} 8.3,1 \mathrm{mM} \mathrm{MgCl}, 1 \mathrm{mM} \mathrm{ZnCl}_{2}$ at $37^{\circ} \mathrm{C}$ for $30 \mathrm{~min}$.

2. Extract the mixture with phenol and ethanol precipitate the RNA.

3. Introduce monophosphate to the 5 '-termini in reactions containing dephosphorylated linear transcript in $20 \mu \mathrm{l}$ reactions containing $50 \mathrm{mM}$ Tris- $\mathrm{HCl} \mathrm{pH} 7.6,10 \mathrm{mM} \mathrm{MgCl}, 100 \mu \mathrm{M}$ ATP, $10 \mathrm{mM}$ dithiothreitol and 5 units of polynucleotide kinase by incubating at $37^{\circ} \mathrm{C}$ for $30 \mathrm{~min}$

4. Heat the mixture at $65^{\circ} \mathrm{C}$ for $10 \mathrm{~min}$ to inactivate the kinase.

5. Circularise the RNA in $50 \mathrm{mM}$ Hepes $\mathrm{pH} 8.3,10 \mathrm{mM} \mathrm{MgCl}, 10 \mathrm{mM}$ dithiothreitol, $1 \mathrm{mM}$ ATP, $10 \%$ dimethylsulfoxide, $2-3 \mu \mathrm{g} / \mathrm{ml}$ linear RNA and 100 units/ml T4 RNA ligase, by incubating at $12^{\circ} \mathrm{C}$ for $4 \mathrm{~h}$
1
2
3

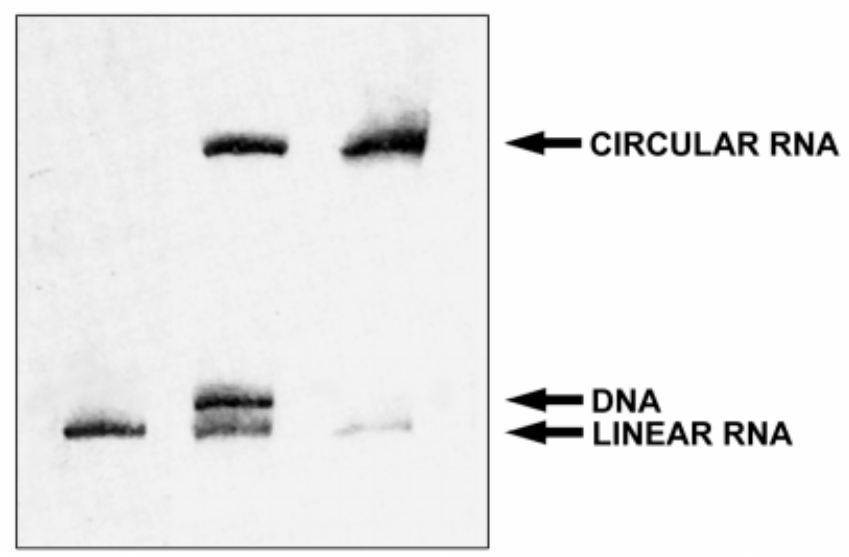

Figure 3. Analysis of linear and circular CEVd RNA transcript by polyacrylamide gel electrophoresis Lane 1: transcription reaction treated with DNase, 2: transcription product after circularisation, 3: CEVd RNA isolated from infected plants. Reproduced from Rigden and Rezaian (8) with permission from Academic Press. 


\section{Other Applications}

Transcription from PCR products as templates has a wide range of applications. The amplified DNA fused to a phage promoter (24) provides an alternative to using cloned DNA as template for transcription and has been used successfully to develop sequencing procedures $(24,25)$. A labelled nucleotide or a ribonucleotide analogue may be incorporated for generating RNA probes or transcripts that can be used in structural studies.

A unique possibility provided by the circular structure of RNA templates using the procedure described here is production of circularly permuted exact-size or partial-size transcripts from a desired region starting with a $G$ nucleotide in the molecule. Synthesis of full-length transcripts of exact size is not practical by cloning techniques due to the nearly unavoidable introduction of vector sequences into the transcripts.

An RNA cleavage system by a ribozyme-containing vector has also been used to produce exact length potato spindle tuber viroid from a $\mathrm{Bam} \mathrm{H} 1$ monomeric clone $(26,27)$. This cloning approach is based on an elaborate vector design in which viroid full-length cDNA is flanked by specially modified versions of two ribozymes derived from tobacco ringspot virus. Transcription of the resulting plasmid DNA produces an RNA that spontaneously self-cleaves to release a unit-length viroid RNA (26). This approach is limited by the availability of compatible restriction sites.

The procedure described here greatly simplifies site-directed mutagenesis of circular RNAs. Nucleotide deletions or insertions may be introduced through design of the primers and larger deletions may be introduced by spacing the two primers apart. In addition to the circular RNAs, the in vitro synthesis system can be adapted to the production of linear RNAs carrying a 5' G nucleotide, such as mRNAs and some viral single stranded RNAs. The transcription step may be linked to an RNA capping reaction (28) to produce functional RNA molecules. The RNA circularisation step itself may be used to increase RNA stability with molecules such as ribozymes when in vivo RNA degradation is of a concern.

\section{Acknowledgement}

I thank Jamus Stonor for the line drawings.

\section{References}

1. Sänger, H.L. 1987. Viroid replication. In: The Viroids. T.O. Diener, ed. Plenum Press, New York. p 117-166.

2. Francki, R.I.B. 1987. Possible viroid origin. Encapsidated viroidlike RNA. In: The Viroids. T.O. Diener, ed. Plenum Press, New York. p 205-218.

3. Wang, K.S., Choo, Q.L., Weiner, A.J., Ou, H.J., Najarian, R.C., Thayer, R.M., Mullenbach, G.T., Deddiston, K.J., Gerin, J.L. and Houghton, M. 1986. Structure, sequence and expression of the hepatitis delta (d) viral genome. Nature (London). 323: 508-514.

4. Cress, D.E., Kiefer, M.C. and Owens, R.A. 1983. Construction of infectious potato spindle tuber viroid cDNA clones. Nucleic Acids Res. 11: 6821-6835.

5. Owens, R.A. and Hammond, R.W. 1987. Molecular biology of viroid-host interactions. In: The Viroids. T.O. Diener, ed. Plenum Press, New York. p 167188.

6. Tabler, M. and Sänger, H.L. 1984. Cloned single- and double-stranded DNA copies of potato spindle tuber viroid (PSTV) RNA and co-inoculated subgenomic DNA fragments are infectious. EMBO J. 3: 3055-3062.

7. Visvader, J.E., Forster, A.C. and Symons, R.H. 1985. Infectivity and in vitro 
mutagenesis of monomeric cDNA clones of citrus exocortis viroid indicates the site of processing of viroid precursors. Nucleic Acids Res. 13: 5843-5856.

8. Rigden, J.E. and Rezaian, M.A. 1992. In vitro synthesis of an infectious viroid: Analysis of the infectivity of monomeric linear CEV. Virology. 186: 201-206.

9. Beaudry, D. and Perreault, J.P. 1995. An efficient strategy for the synthesis of circular RNA molecules. Nucleic Acids Res. 23: 3064-3066.

10. Milligan, J.F., Groebe, D.R., Witherell, G.W. and Uhlenbeck, O.C. 1987. Oligoribonucleotide synthesis using T7 RNA polymerase and synthetic DNA templates Nucleic Acids Res. 15: 8783-8798.

11. Bussiere, F., Lafontaine, D. and Perreault, J.P. 1996. Compilation and analysis of viroid and viroid-like RNA sequences. Nucleic Acids Res. 24: 1793-1798.

12. Froussard, P. 1992. A random - PCR method (rPCR) to construct whole cDNA library from low amounts of DNA. Nucleic Acids Res. 20: 2900.

13. Navarro, B., Daros, J.A. and Flores, R. 1998. Reverse transcription polymerase chain reaction protocols for cloning small circular RNAs. J. Virol. Methods. 73: 1-9.

14. Palukaitis, P. and Symons, R.H. 1980. Purification and characterization of the circular and linear forms of chrysanthemum stunt viroid. J. Gen. Virol. 46: 477489.

15. Schumacher, J., Randles, J.W. and Riesner, D. 1983. A two-dimensional electrophoretic technique for the detection of circular viroids and virusoids. Analytical Biochem. 135: 288-295.

16. Goblet, C., Prost, E. and Whalen, R.G. 1989. One step amplification of transcripts in total RNA using the polymerase chain reaction. Nucleic Acids Res. 17: 2144.

17. Melton, D.A., Krieg, P.A., Rebagliati, M.R., Maniatis, T., Zinn, K. and Green, M.R. 1984. Efficient in vitro synthesis of biologically active RNA and RNA hybridization probes from plasmids containing a bacteriophage SP6 promoter. Nucleic Acids Res. 12: 7035-7056.

18. Sambrook, J., Fritch, E.F. and Maniatis, T. 1989. Molecular Cloning: A Laboratory Manual. Cold Spring Harbor Laboratory Press, Cold Spring Harbor, New York.

19. Merril, C.R., Goldman, D., Sedman, S.A. and Ebert, M.H. 1981. Ultrasensitive stain for proteins in polyacrylamide gels shows regional variation in cerebrospinal fluid proteins. Science. 211: 1437-1438.

20. Uhlenbeck, O.C. and Gumport, R.I. 1982. T4 RNA ligase. In: The Enzymes, Volume 15. P.D. Boyer, ed. Academic Press, New York. p 31-58.

21. Clark, J.M. 1988. Novel non-templated nucleotide addition reaction catalized by prokaryotic and eukaryotic DNA polymerases. Nucleic Acids Res. 16: 9677 9686.

22. Bachmann, B., Luke, W. and Hunsmann, G. 1990. Improvement of PCR amplified DNA sequencing with the aid of detergents. Nucleic Acids Res. 18: 1309.

23. Gast, F-U., Kemp, D., Spieker, R.L. and Sänger, H.L. 1996. Secondary structure of potato spindle tuber viroid (PSTVd) and sequence comparison with other small pathogenic RNA replicons provide evidence for central non-canonical base-pairs, large A rich loop, and a terminal branch. J. Mol. Biol. 262: 652-670.

24. Stoflet, E.S., Koeberl, D.D. Sarkar, G. and Sommer, S.S. 1988. Genomic amplification with transcript sequencing. Science. 239: 491-494.

25. Sarkar, G and Sommer, S.S. 1989. Access to a messenger RNA sequence or its protein product is not limited by tissue or species specificity. Science. 244: 331-334

26. Owens, R.A., Steger, G., Hu, Y., Fels, A., Hamond, R.W. and Riesner, D. 1996. RNA structural features responsible for potato spindle tuber viroid pathogenicity. Virology. 222: 144-158. 
27. Feldstein, P.A., Hu, Y. and Owens, R.A. 1998. Precisely full length, circularizable, complementary RNA: An infectious form of potato spindle tuber viroid. Proc. Natl. Acad. Sci. USA. 95: 6560-6565.

28. Contreras, R., Cheroutre, H., Degrave, W. and Fiers, W. 1982. Simple efficient in vitro synthesis of capped RNA useful for direct expression of cloned eukaryotic genes. Nucleic Acids Res. 10:6353-6362. 


\section{Further Reading}

Caister Academic Press is a leading academic publisher of advanced texts in microbiology, molecular biology and medical research. Full details of all our publications at caister.com

- MALDI-TOF Mass Spectrometry in Microbiology Edited by: M Kostrzewa, S Schubert (2016) www.caister.com/malditof

- Aspergillus and Penicillium in the Post-genomic Era Edited by: RP Vries, IB Gelber, MR Andersen (2016) www.caister.com/aspergillus2

- The Bacteriocins: Current Knowledge and Future Prospects Edited by: RL Dorit, SM Roy, MA Riley (2016)

www.caister.com/bacteriocins

- Omics in Plant Disease Resistance Edited by: V Bhadauria (2016) www.caister.com/opd

- Acidophiles: Life in Extremely Acidic Environments Edited by: R Quatrini, DB Johnson (2016) www.caister.com/acidophiles

- Climate Change and Microbial Ecology: Current Research and Future Trend

Edited by: J Marxsen (2016)

www.caister.com/climate

- Biofilms in Bioremediation: Current Research and Emerging Technologies

Edited by: G Lear (2016)

www.caister.com/biorem

- Microalgae: Current Research and Applications Edited by: MN Tsaloglou (2016) www.caister.com/microalgae

- Gas Plasma Sterilization in Microbiology: Theory, Applications, Pitfalls and New Perspectives Edited by: H Shintani, A Sakudo (2016) www.caister.com/gasplasma

- Virus Evolution: Current Research and Future Directions Edited by: SC Weaver, M Denison, M Roossinck, et al. (2016) www.caister.com/virusevol

- Arboviruses: Molecular Biology, Evolution and Control Edited by: N Vasilakis, DJ Gubler (2016) www.caister.com/arbo

- Shigella: Molecular and Cellular Biology Edited by: WD Picking, WL Picking (2016) www.caister.com/shigella

-Aquatic Biofilms: Ecology, Water Quality and Wastewater Treatment

Edited by: AM Romaní, H Guasch, MD Balaguer (2016)

www.caister.com/aquaticbiofilms

- Alphaviruses: Current Biology

Edited by: S Mahalingam, L Herrero, B Herring (2016)

www.caister.com/alpha

- Thermophilic Microorganisms

Edited by: F Li (2015)

www.caister.com/thermophile
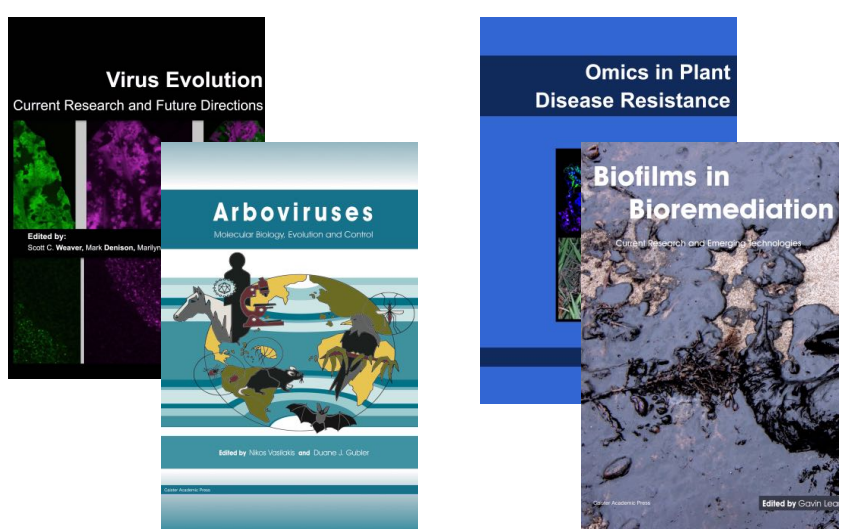
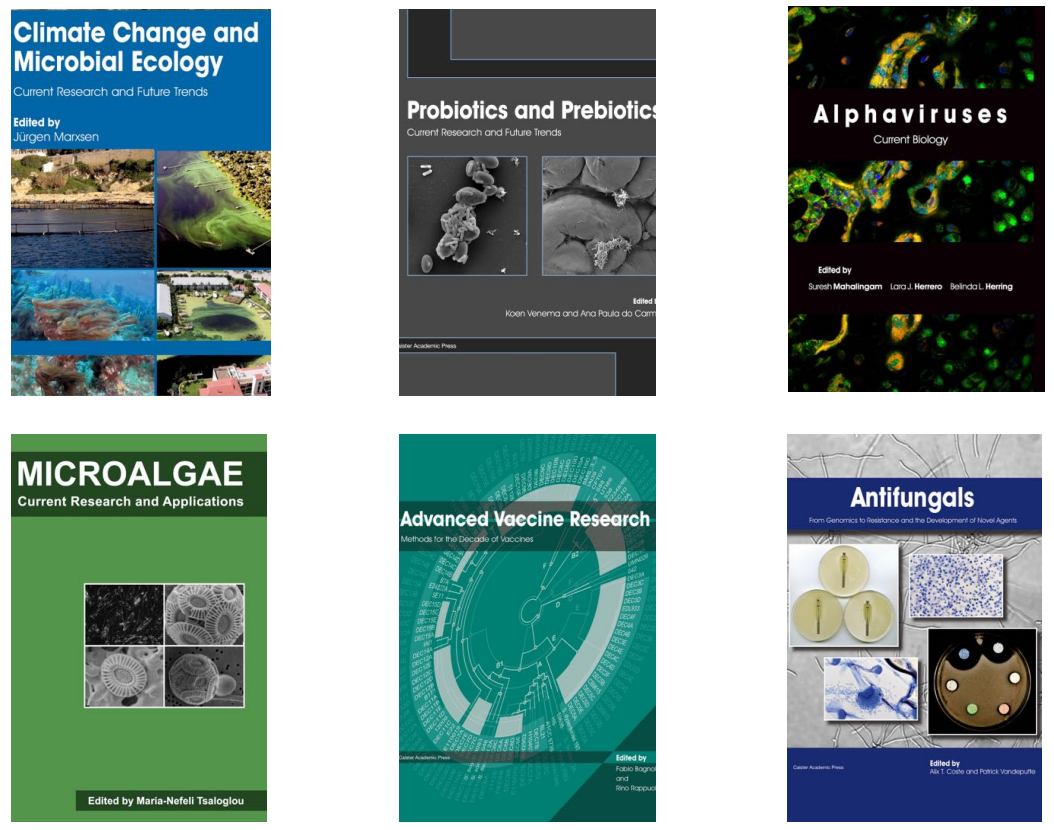

- Flow Cytometry in Microbiology: Technology and Applications Edited by: MG Wilkinson (2015) www.caister.com/flow

- Probiotics and Prebiotics: Current Research and Future Trends Edited by: K Venema, AP Carmo (2015) www.caister.com/probiotics

- Epigenetics: Current Research and Emerging Trends Edited by: BP Chadwick (2015) www.caister.com/epigenetics2015

- Corynebacterium glutamicum: From Systems Biology to Biotechnological Applications

Edited by: A Burkovski (2015)

www.caister.com/cory2

- Advanced Vaccine Research Methods for the Decade of Vaccines

Edited by: F Bagnoli, R Rappuoli (2015)

www.caister.com/vaccines

- Antifungals: From Genomics to Resistance and the Development of Novel Agents

Edited by: AT Coste, P Vandeputte (2015)

www.caister.com/antifungals

- Bacteria-Plant Interactions: Advanced Research and Future Trends Edited by: J Murillo, BA Vinatzer, RW Jackson, et al. (2015) www.caister.com/bacteria-plant

\section{- Aeromonas}

Edited by: J Graf (2015)

www.caister.com/aeromonas

- Antibiotics: Current Innovations and Future Trends

Edited by: S Sánchez, AL Demain (2015)

www.caister.com/antibiotics

- Leishmania: Current Biology and Contro Edited by: S Adak, R Datta (2015) www.caister.com/leish2

- Acanthamoeba: Biology and Pathogenesis (2nd edition) Author: NA Khan (2015)

www.caister.com/acanthamoeba2

- Microarrays: Current Technology, Innovations and Applications Edited by: Z He (2014)

www.caister.com/microarrays2

- Metagenomics of the Microbial Nitrogen Cycle: Theory, Methods and Applications

Edited by: D Marco (2014)

www.caister.com/n2 